\title{
In vitro anthelmintic activity of aqueous and ethanol extracts of Paraserianthes falcataria bark waste against Haemonchus contortus obtained from a local slaughterhouse in Indonesia
}

\author{
Zein Ahmad Baihaqi1 ${ }^{10}$, Irkham Widiyono² (D) and Wisnu Nurcahyo ${ }^{3}$ (D)
}

\begin{abstract}
1. Student of Doctoral Program Veterinary Science, Faculty of Veterinary Medicine, Universitas Gadjah Mada, Yogyakarta, Indonesia; 2. Department of Internal Medicine, Faculty of Veterinary Medicine, Universitas Gadjah Mada, Yogyakarta, Indonesia; 3. Department of Parasitology, Faculty of Veterinary Medicine, Universitas Gadjah Mada, Yogyakarta, Indonesia. Corresponding author: Irkham Widiyono, e-mail: irkhamwidiyono@ugm.ac.id Co-authors: ZAB: zein.ahmad.b@mail.ugm.ac.id, WN: wisnu-nc@ugm.ac.id

Received: 25-02-2020, Accepted: 12-06-2020, Published online: 11-08-2020
\end{abstract}

doi: www.doi.org/10.14202/vetworld.2020.1549-1554 How to cite this article: Baihaqi ZA, Widiyono I, Nurcahyo W (2020) In vitro anthelmintic activity of aqueous and ethanol extracts of Paraserianthes falcataria bark waste against Haemonchus contortus obtained from a local slaughterhouse in Indonesia, Veterinary World, 13(8): 1549-1554.

\begin{abstract}
Aim: This study was conducted to determine the anthelmintic activity of aqueous and ethanol extracts of Paraserianthes falcataria bark against Haemonchus contortus.

Materials and Methods: Ethanol extract of bark (E.E.B.) waste and aqueous extract of bark (A.E.B.) waste of $P$. falcataria (at concentrations $0,0.2,0.4,0.8,1,2.5$, and $5 \%)$ and albendazole $(2 \mathrm{mg} / \mathrm{ml})$ as the positive control were placed in separate Petri dishes $(50 \mathrm{~mm})$. Twenty $H$. contortus worms were placed in Petri dishes and incubated at $37^{\circ} \mathrm{C}$ for $0.5,1,2,3,4,5,6$, and $12 \mathrm{~h}$. Mortality of each worm was ensured by pressing the body of the worm with a pair of tweezers and keeping it in lukewarm water for $5 \mathrm{~min}$ before declaring it dead. Mortality is defined as amount of death individuals and time of mortality of each worm was recorded. The parasites were then observed using scanning electron microscopy (SEM) at an accelerating voltage of $15 \mathrm{Kv}$. Statistical analysis was performed using SPSS 21.0 software, two-way ANOVA followed by Tukey's test to detect significant differences $(\mathrm{p}<0.05)$. The result was expressed as the mean \pm standard deviation.

Results: The E.E.B. and A.E.B. of P. falcataria contained active compounds, such as tannin, alkaloid, flavonoid, saponin, steroid, and triterpenoid. E.E.B. had a higher content of phenol, while A.E.B. had a higher content of flavonoid. In this study, $P$. falcataria showed a significant effect $(\mathrm{p}=0.00)$ on $H$. contortus in vitro. E.E.B. $(0.8 \%)$ was able to exterminate H. contortus completely after $6 \mathrm{~h}$, more effective than A.E.B. (5\%) while the positive control requires $(2 \mathrm{mg} / \mathrm{ml}) \mathrm{after} 2 \mathrm{~h}$. SEM analysis of the worm treated with E.E.B. and A.E.B. showed damaged cuticle structure.
\end{abstract}

Conclusion: The aqueous and ethanol extracts of $P$. falcataria bark waste demonstrated anthelmintic activity against $H$. contortus.

Keywords: anthelmintic, bark, Haemonchus contortus, prevalence, scanning electron microscopy.

\section{Introduction}

Haemonchus contortus is one of the most important parasitic nematodes of ruminant livestock worldwide [1]. Cortes-Morales et al. [2] stated that $H$. contortus caused large production losses worldwide and worm infestation caused an infection characterized by weight loss, diarrhea, anemia, edema, ill-thrift, acute weakness, and eventually death. $H$. contortus is a blood-sucking parasite found mostly in the small abomasum of ruminant livestock. Niciura et al. [3] added that the gastrointestinal nematode significantly affected the sheep livestock and was viewed as the most pathogenic parasite in tropical areas. Baihaqi et al. [4] stated that the parasitic worm with the highest prevalence in Wonosobo Regency, Indonesia, was $H$. contortus, followed by Ostertagia spp., Trichostrongylus spp., Bunostomumspp., Trichuris

Copyright: Baihaqi, et al. Open Access. This article is distributed under the terms of the Creative Commons Attribution 4.0 International License (http://creativecommons.org/licenses/ by/4.0/), which permits unrestricted use, distribution, and reproduction in any medium, provided you give appropriate credit to the original author(s) and the source, provide a link to the Creative Commons license, and indicate if changes were made. The Creative Commons Public Domain Dedication waiver (http:// creativecommons.org/publicdomain/zero/1.0/) applies to the data made available in this article, unless otherwise stated. spp., and Moniezia spp., during the dry and rainy seasons. The tropical environmental conditions in Indonesia constitute an ideal habitat for parasitic species.

Secondary metabolite compounds of plants showed bioactivity toward $H$. contortus which is resistant to the multidrugs given to small ruminants [5]. Zarza-Albarrán et al. [6] stated that pressing the nematode showed the presence of phenolic compounds in the plant extracts that were responsible for the anthelmintic effect. Maestrini et al. [7] added that secondary metabolite compounds present in plant extracts were responsible for the anthelmintic activity. Carvalho et al. [8] added that phenolic compounds, tannins, and flavonoids, such as those in Stylosanthes guianensis, were effective against eggs and larvae of gastrointestinal parasites and could be considered as potential alternative naturally anthelmintic treatments. Kommuru et al. [9] stated that the worms that interacted with the condensate tannin showed shrunken and tangled cuticle surfaces.

Large wastes from the agricultural industry can pose a severe environmental issue [10]. FAO revealed that approximately 55 million metric tons of waste were produced from processing, packaging, and distribution in the plant production process [11]. Sagar et al. [12] stated

Veterinary World, EISSN: 2231-0916 
that plant waste, including seeds, fruit skin, and plant bark containing a number of bioactive compound sources could be used to support the other sectors. Krisnawati et al. [13] stated that Paraserianthes falcataria is a native plant of the eastern regions of Indonesia (Sulawesi, Papua, and Maluku). Nawir et al. [14] stated that the manufacturing industries of $P$. falcataria in Wonosobo Regency rapidly developed due to the high demand of P. falcataria in Japan. Roheem et al. [15] added that bark waste could be used effectively as alternative medicine because it contains active compounds. King et al. [16] stated that Albizia falcataria plant contains alkaloids, tannins, flavonoids, saponins, steroids, and triterpenoids.

This research was aimed at determining the anthelmintic potency of $P$. falcataria (Sengon) bark waste with aqueous and ethanol extracts toward $H$. contortus nematodes.

\section{Materials and Methods \\ Ethical approval}

This research was approved by the Institutional Ethical Committee, Faculty of Veterinary Medicine, Universitas Gadjah Mada, Yogyakarta, Indonesia. Number: 0013/EC-FKH/Int./2019.

\section{Study period and location}

This study was conducted from October 14, 2019 until November 23, 2019 in Animal Parasitology Laboratorium, Department of Internal Medicine, Faculty of Veterinary Medicine, Universitas Gadjah Mada, Indonesia.

\section{Plant waste collection and extraction}

$P$. falcataria bark waste was collected from the plantation industry in Wonosobo Regency, Central Java, Indonesia. The extraction was performed at room temperature after samples were air-dried and finely powdered using a grinder. The extract used in the treatment was divided into two which were ethanol extract of bark (E.E.B.) and aqueous extract of bark (A.E.B.). One hundred grams of $P$. falcataria bark waste were macerated in water and ethanol for $48 \mathrm{~h}$ with intermittent shaking. The extract was then filtered through Whatman filter paper No.1. and concentrated under vacuum on a rotary evaporator [17].

\section{Determination of plant phytochemistry}

To detect the bioactive compounds such as alkaloids, flavonoids, phenols, tannins, steroids, and alkaloids, both the aqueous and ethanol extracts were subjected to qualitative phytochemical screening using standard procedures [18]. The total phenolic content in the plant waste extracts was measured using FolinCiocalteu method and the results were expressed as mg gallic acid equivalents [19], while the total flavonoid content of plant waste extracts was determined using colorimetric method and the results were expressed as $\mathrm{mg}$ rutin (RE), as previously reported [20].

\section{In vitro adult worm mortality test}

The adult female worms of $H$. contortus were collected from the slaughterhouse for sheep in
Godean, Yogyakarta. The in vitro anthelmintic study was modified [21]. The aqueous and ethanol extracts of $P$. falcataria bark waste $(0,0.2,0.4,0.8,1,2.5$, and $5 \%)$ were placed in a Petri dish $(50 \mathrm{~mm}) ; 20$ adult worms of $H$. contortus were incubated at $37^{\circ} \mathrm{C}$ for 0.5 , $1,2,3,4,5,6$, and $12 \mathrm{~h}$, using $2 \mathrm{mg} / \mathrm{ml}$ albendazole (Kimia Farma, Indonesia) as the positive control. The procedure was performed daily for 3 days. The death of the worm was secured by pressing the body of the worm using a pair of tweezers and keeping it in lukewarm water for some time before declaring it dead. Mortality is defined as amount of death individuals and time of mortality of each worm was recorded.

\section{Scanning electron microscopy (SEM)}

The worms obtained from the in vitro assay studies were fixed with $2 \%$ glutaraldehyde solution with sodium cacodylate as buffer $(0.1 \mathrm{M})$ for $4 \mathrm{~h}$ at $4^{\circ} \mathrm{C}$. After two washes in the same buffer $(0.2 \mathrm{M})$, the worms were dehydrated in a graded ethanol series, dried by critical point drying with EMSCOPE CPD 750, and coated with gold-palladium for $5 \mathrm{~min}$ at $100 \AA / \mathrm{min}$. The parasites were then observed with S450 scanning electron microscope (Hitachi) at an accelerating voltage of $15 \mathrm{Kv}$ [22].

\section{Statistical analysis}

The results of in vitro mortality of $H$. contortus were recorded and analyzed by SPSS 21.0. We performed a two-way ANOVA followed by Tukey's test to detect significant differences $(p<0.05)$. The result was expressed as the mean \pm standard deviation.

\section{Results}

The presence of the two solvents showed a positive effect qualitatively on secondary metabolite compounds such as tannins, flavonoids, alkaloids, saponins, and steroids (Table-1).

Table-2 shows the total phenol and flavonoid contents in P. falcataria bark wastes with aqueous and $70 \%$ ethanol extracts. The highest total phenolic

Table-1: Qualitative phytochemical analysis.

\begin{tabular}{lcc}
\hline $\begin{array}{l}\text { Secondary } \\
\text { metabolite }\end{array}$ & \multicolumn{2}{c}{ Bark of Paraserianthes falcataria } \\
\cline { 2 - 3 } & Aqueous & 70\% ethanol \\
\hline Tannin & + & + \\
Flavonoid & + & + \\
Alkaloid & + & + \\
Saponin & + & + \\
Steroid & + & + \\
\hline
\end{tabular}

Table-2: Total phenol and flavonoid contents in the studied plant in $\mathrm{mg} / \mathrm{g}$ dry weight.

\begin{tabular}{lcc}
\hline Plant extract & $\begin{array}{c}\text { Total phenolic } \\
\text { (mg GAE/g dw) }\end{array}$ & $\begin{array}{c}\text { Flavonoids } \\
\text { content } \\
\text { (mg RE/g dw) }\end{array}$ \\
\hline $\begin{array}{l}\text { E.E.B. Paraserianthes } \\
\text { falcataria }\end{array}$ & 10 & 1.6 \\
$\begin{array}{l}\text { A.E.B. Paraserianthes } \\
\text { falcataria }\end{array}$ & 7.5 & 3.3 \\
\hline $\begin{array}{l}\text { E.E.B: Ethanol extract of bark, A.E.B: Aqueous extract of } \\
\text { bark }\end{array}$
\end{tabular}


content was observed in E.E.B. P. falcataria $(10 \mathrm{mg}$ $\mathrm{GAE} / \mathrm{g} \mathrm{dw}$ ) while the highest total flavonoid content was observed in A.E.B. P. falcataria (3.3 $\mathrm{mg} \mathrm{RE} / \mathrm{g} \mathrm{dw}$ ).

Table-3 shows that E.E.B. P. falcataria significantly $(\mathrm{p}=0.00)$ caused the death of $H$. contortus in vitro, starting at treatments $0.2 \%$ after $3 \mathrm{~h}$, while the A.E.B. P. falcataria was observed to start inhibiting at a concentration of $0.2 \%$ at $2 \mathrm{~h}$ into the experiment (Table-4). Positive control (albendazole) was observed to start worm death in the $1^{\text {st }}$ half an hour by $61.67 \pm 15.28$ and $100 \%$ worm death by the $2^{\text {nd }}$ h. E.E.B. P. falcataria was controlled to have $100 \%$ lethal ability toward $H$. contortus at a lower concentration $(0.8 \%)$ than A.E.B. $(5 \%)$.

\section{Discussion}

Qualitatively, the phytochemical analysis on the aqueous and $70 \%$ ethanol extracts of $P$. falcataria bark waste was found positive for active compounds in the form of tannins, flavonoids, alkaloids, saponins, and steroids. The results of a study conducted by Raipuria et al. [23] showed that the aqueous and ethanol extracts used in the analysis of active compounds in plants were qualitatively equal and in vivo assays could be used for reference. Amadioha and Chidi stated that aqueous and ethanol extracts qualitatively showed no differences when analyzed for active compounds in plants. Active phytochemicals are naturally produced by plants to help them suppress diseases or pathogenic organisms [24]. Cheruiyot et al. [25] added that phytochemical screening of plants was used to determine potentially active compounds in plants.

Phenol compounds are natural active secondary metabolites of plants that can be used as a defense to protect the plant from parasitic infections [26]. Montoro et al. [27] stated that flavonoids are naturally found in plants and are believed to have several effects on plant health. The studies on flavonoid derivatives proved that flavonoids have antibacterial, anthelmintic, antiviral, anti-inflammatory, anti-allergic, and anticancer activities. Plant active compounds were proved to suppress $H$. contortus [28-31]. Badar et al. [32] stated that the variation in anthelmintic activity in vitro could be affected by the type of solvent extracts of plants and the difference in the content of active compounds in bark of plants.

The first $100 \%$ inhibition and suppression of $H$. contortus was monitored faster for ethanol extract than aqueous extract of $P$. falcataria. These results were the same as the findings of Kumari et al. [33] stated that anthelmintic observations using solvent extracts of Azadirachta indica were more easily monitored because $100 \%$ suppression required only $2 \mathrm{~g} / \mathrm{l}$ of ethanol extract and $3.5 \mathrm{~g} / \mathrm{l}$ of aqueous extract. At concentration $1 \mathrm{~g} / \mathrm{l}$, ethanol extract showed $50 \%$ suppression while aqueous extract still showed $0 \%$ suppression [33]. Cala et al. [34] stated that in vitro observations of the inhibition of anthelmintic effects toward $H$. contortus by the utilization of secondary metabolite compounds in plants were influenced by the type of solvent used, the dosage, and the type of plant used.

Figure-1 shows that the observed change in SEM images in the in vitro experiment revealed the interaction between E.E.B and A.E.B. Control worms ( $a$ and $b$ ) were observed to be smooth, free of aggregates on the cuticle, and having an undamaged reticular longitudinal back, whereas worms that received treatments $(b, c, e$, and $\mathrm{f}$ ) were observed to be damaged at the buccal area and show aggregate buildup in the annular cuticles. Findings from research by Acevado-Ramírez et al.[21] showed that the effects of anthelmintic activity of Castanea sativa on $H$. contortus were destruction around the mouth, anus, vulva, and bursa copulatrix, and loss of cuticle structure integrity in the mid-section of the body coupled with expulsion of digestive tract components. Tresia et al. [35] stated that anthelmintic activity was synergistically carried out by active compounds of plant by damaging the cuticle and changing the shape of the pore and permeability of the worm cuticle. Sambodo et al. [36] added that cuticle changes due to interactions with aqueous extract of Biophytum petersianum, where the part has an important role in the motility and absorption of nutrients.

SEM results revealed severe damage to the cuticle of $H$. contortus after contact with Leucosidea
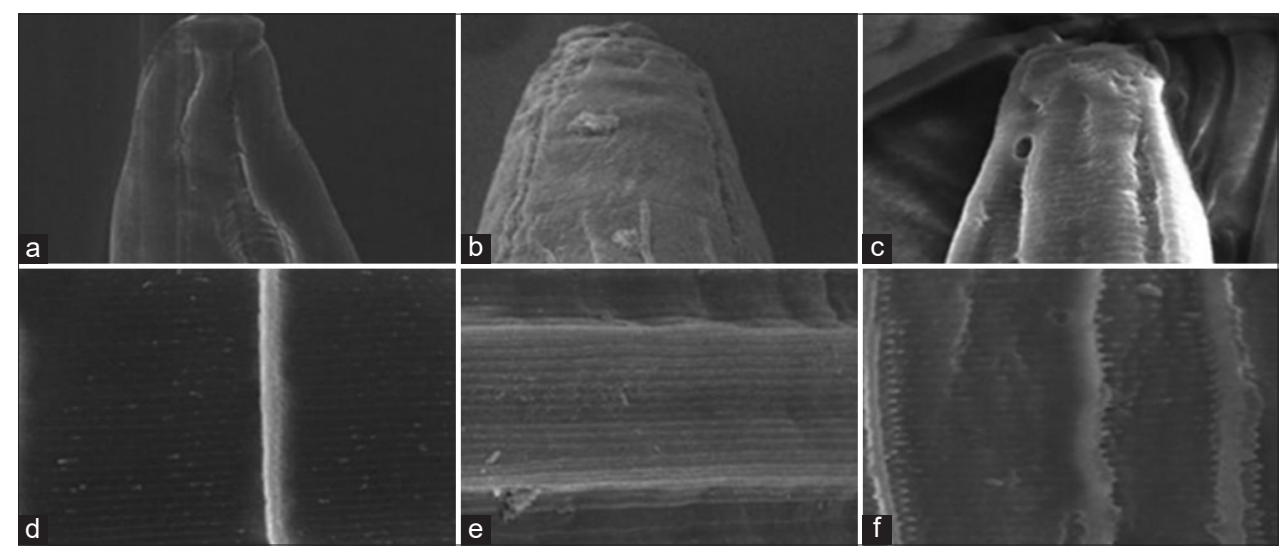

Figure-1: Scanning electron microscopy image of the anterior end and the cuticle of the adult female Haemonchus contortus. (a) and (d) The normal fresh worm; (b) and (e) the worm after incubation with E.E.B.; and (c) and (f) the worm after incubation with A.E.B.

Veterinary World, EISSN: 2231-0916 

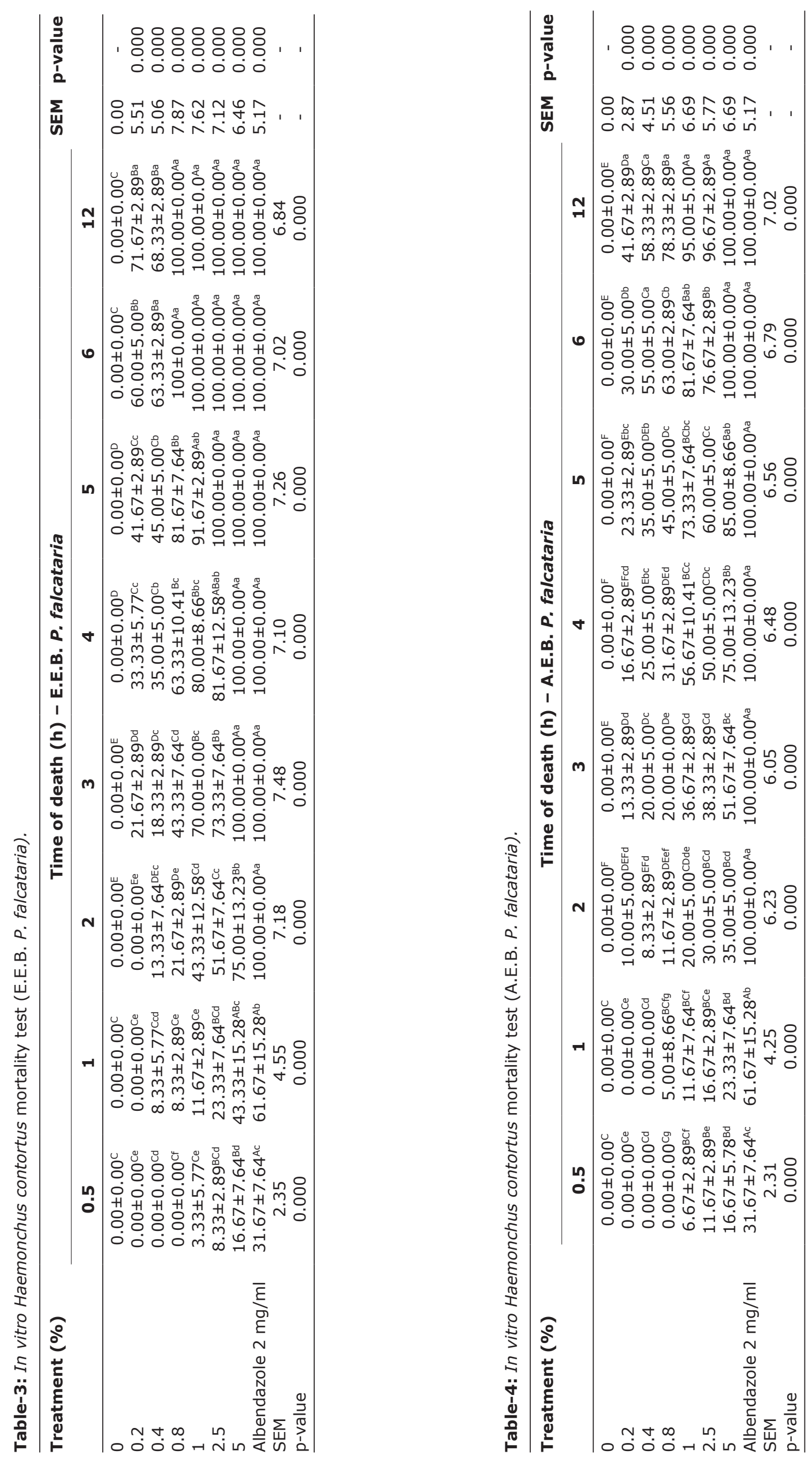
sericea leaf extract and agrimol G component [37]. Yoshihara et al. [38] added that the structural changes in the cuticle caused nutritional disorders in the nematodes that could eventually lead to malnutrition. Olivas-Aguirre et al. [39] added that the mechanism of damage to body parts of the nematodes on contact with active plant compounds was by the formation of complex collagen-tannins due to the high content of proline in collagen or nematode cuticle damage by secondary metabolite compounds in plants.

\section{Conclusion}

This research showed that the aqueous and ethanol extracts of $P$. falcataria bark waste contained tannins, flavonoids, alkaloids, saponins, and steroids and were, hence, able to deactivate $H$. contortus. This was proved from the results of the mortality test and the structural changes and damage to the cuticle and the longitudinal reticular back of the worms.

\section{Authors' Contributions}

ZAB, IW, and WN designed the study. ZAB conducted the field survey. ZAB, IW, and WN collected samples and examined in the laboratory. All authors drafted and revised the manuscript. All authors have read and approved the final manuscript.

\section{Acknowledgments}

This study was supported by Program Rekognisi Tugas Akhir Direktorat Penelitian Universitas Gadjah Mada, Indonesia. Program Grant Number 2127/UN1/ DITLIT/DIT-LIT/LT/2019.

\section{Competing Interests} interests.

The authors declare that they have no competing

\section{Publisher's Note}

Veterinary World remains neutral with regard to jurisdictional claims in published institutional affiliation.

\section{References}

1. Wang, T., Ma, G., Ang, C., Korhonen, P.K., Xu, R., Nie, S., Koehler, A.V., Simpson, R.J., Greening, D.W., Reid, G.E., Williamson, N.A. and Gasser, R.B. (2019) Somatic proteome of Haemonchus contortus. Int. J. Parasitol., 49(3-4): 311-320

2. Cortes-Morales, J.A., Olmedo-Juárez, A., Trejo-Tapia, G., González-Cortazar, M., Domínguez-Mendoza, B.E., Mendoza-de Gives, P. and Zamilpa, A. (2019) In vitro ovicidal activity of Baccharis conferta Kunth against Haemonchus contortus. Exp. Parasitol., 197: 20-28.

3. Niciura, S.C.M., Cruvinel, G.G., Moraes, C.V., Chagas, A.C.S., Esteves, S.N., Benavides, M.V. and Amarante, A.F.T. (2019) In vivo selection for Haemonchus contortus resistance to monepantel. J. Helminthol., 94(e46): 1-5.

4. Baihaqi, Z.A., Widiyono, I. and Nurcahyo, W. (2019) Prevalence of gastrointestinal worms in Wonosobo and thin-tailed sheep on the slope of Mount Sumbing, Central Java, Indonesia. Vet. World, 12(11): 1866-1871.

5. Barone, C.D., Zajac, A.M., Manzi-Smith, L.A. Howell, A.B., Reed, J.D., Kruegerd, C.G. and Petersson, K.H. (2018)
Anthelmintic efficacy of cranberry vine extracts on ovine Haemonchus contortus. Vet. Parasitol., 253: 122-129.

6. Zarza-Albarrán, M.A., Olmedo-Juárez, A., Rojo-Rubio, R., Mendoza-de Gives, P., González-Cortazar, M., TapiaMaruri, D., Mondragon-Ancelmo, J., García-Hernández, C., BléGonzález, E.A. and Zamilpa, A. (2019) Galloyl flavonoids from Acacia farnesiana pods possess potent anthelmintic activity against Haemonchus contortus eggs and infective larvae. J. Ethnopharmacol., 249:112402.

7. Maestrini, M., Tava, A., Mancini, S., Tedesco, D. and Perrucci, S. (2020) In Vitro anthelmintic activity of saponins from Medicago spp. Against sheep gastrointestinal nematodes. Molecules, 25(2): 242.

8. Carvalho, V.F., Ramos, L.A., da Silva, C.A., Nebo, L., Moraes, D., da Silva, F.F.A., da Costa, N.C.A., de Rodrigues Junior, R.O., de Souza, L.F. and Rodrigues, R.M. (2020) In vitro anthelmintic activity of Siparuna guianensis extract and essential oil against Strongyloides venezuelensis. J. Helminthol., 94 (e50): 1-5.

9. Kommuru, D.S., Whitley, N.C., Miller, J.E., Mosjidis, J.A., Burke, J.M., Gujja, S., Mechineni, A. and Terrill, T.H. (2014) Effect of Sericea lespedeza leaf meal pellets on adult female Haemonchus contortus in goats. Vet. Parasitol., 207(1-2): 170-175.

10. Tripathi, N., Hills, C.D., Singh, R.S. and Atkinson, C.J. (2019) Biomass waste utilisation in low-carbon products: Harnessing a major potential resource. Npj Clim. Atmos. Sci., 2(1):1-10

11. FAO. (2014) Definitional Framework of Food Losses and Waste. FAO, Rome, Italy.

12. Sagar, N.A., Pareek, S., Sharma, S., Yahia, E.M. and Lobo, G. (2018) Fruit and vegetable waste: Bioactive compounds, their extraction, and possible utilization. Compr. Rev. Food Sci. Food Saf., 17(3): 512-531.

13. Krisnawati, H., Varis, E., Kallio, M. and Kanninen, M. (2011) Paraserianthes falcataria (L.) Nielsen: Ecology, Silviculture and Productivity. Center for International Forestry Research (CIFOR), Bogor, Indonesia.

14. Nawir A.A., Murniati, and Rumboko, L. (2008) Rahabilitasi Hutan di Indonesia. Center for Internasional Forestry Research (CIFOR), Bogor, Inodonesia

15. Roheem, F.O., Soad, S.Z.M., Ahmed, Q.U., Shah, S.A.A., Latip, J. and Zakaria, Z.A. (2019) Evaluation of the enzyme inhibitory and antioxidant activities of Entada spiralis stem bark and isolation of the active constituents. Molecules, 24(6): 1006

16. King, M., Catranis, C., Soria, J.A. and Leigh, M.B. (2016) Phytochemical and toxicological analysis of Albizia falcataria sawdust. Int. Wood Prod. J., 4(4): 232-241.

17. Eruygur, N., Koçyiğit, U.M., Taslimi, P., Ataş, M., Tekin, M. and Gülçin, İ. (2018) Screening the in vitro antioxidant, antimicrobial, anticholinesterase, antidiabetic activities of endemic Achillea cucullata (Asteraceae) ethanol extract. $S$. Afr. J. Bot., 120 (4): 141-145.

18. Trease, G.E. and Evans, W.C. (2002) Pharmacognosy. $15^{\text {th }}$ ed. Saunders Publishers, London. p391-393.

19. Lister, E. and Wilson, P. (2001) Measurement of Total Phenolic and ABTS Assay for Antioxidant Activity. Crop Research Institute, Lincoln, New Zealand.

20. Nabavi, S.M., Ebrahmzadeh, M.A., Nabavi, S.F. and Jafari, M. (2008) Free radical scavenging activity and antioxidant capacity of Eryngium caucasicum Trautv and Froripia Subpinnata. Pharmacologyonline, 3: 19-25.

21. Acevado-Ramírez, P.M.C., Calleros, C.H., Pérez, I.F., Hurtado, F.A., Mendoza-Garfías, M.B., Campo, N.C. and Barajas, R. (2019) Anthelmintic effect and tissue alterations induced in vitro by hydrolysable tannins on the adult stage of the gastrointestinal nematode Haemonchus contortus. Vet. Parasitol., 266: 1-6.

22. Montellano, C.M., Arroyo-López, C., Fourquaux, I., TorresAcosta, J.F.J., Sandoval-Castro, C.A. and Hoste, H. (2013) Scanning electron microscopy of Haemonchus contortus 
exposed to tannin-rich plants under in vivo and in vitro conditions. Exp. Parasitol., 133(3): 281-286.

23. Raipuria, N., Kori, D., Saxena, H.O., Pawar, G. and Choubey, S.K. (2018) Qualitative and quantitative evaluation of secondary metabolites in leaves, roots, and stem of Cleome viscosa L. Int. J. Green Pharm., 12(4): 285.

24. Amadioha, A.C. and Chidi, K.P. (2019) Phytochemical composition of aqueous and ethanolic leaf extracts of Piper guineense, Cassia alata, Tagetes erecta, and Ocimum graticimum. Int. J. Pharm. Res., 26(3): 1-8.

25. Cheruiyot, K., Kutima, H., Kareru, P.G., Njonge, F., Odhiambo, R., Mutembei, J. and Madivoli, E. (2015) In vitro ovicidal activity of encapsulated ethanolic extracts of Prosopis juliflora against Haemonchus contortus eggs. J. Pharm. Biol. Sci., 10(5): 18-22.

26. Tamokou, J.D., Mbaveng, A.T. and Kuete, V. (2017) Antimicrobial activities of African spices and vegetables. In: Kuete, V., editor. Medicinal Spices and Vegetables from Africa. Elsevier, Amsterdam, Netherlands. p207-237.

27. Montoro, P., Braca, A., Pizza, C. and De Tommasi, N. (2005) Structure antioxidant activity relationships of flavonoids isolated from different plant species. Food Chem., 92(2): 349-355.

28. Méndez-Ortiz, F.A., Sandoval-Castro, C.A., VenturaCordero, J., Sarmiento-Franco, L.A., Santos-Ricalde, R.H. and Torres-Acosta, J.F.J. (2019) Gymnopodium floribundum fodder as a model for the in vivo evaluation of nutraceutical value against Haemonchus contortus. Trop. Anim. Health Prod., 51(6): 1591-1599.

29. De Jesús-Martinez, X., Olmedo-Juárez, A., OlivaresPérez, J., Zamilpa, A., Gives, P.M., López-Arellano, M.E., Rojas-Hernández, S., Villa-Mancera, A. CamachoD-az, L.M. and Cipriano-Salazar, M. (2018) In Vitro anthelmintic activity of methanolic extract from Caesalpinia coriaria J. willd fruits against Haemonchus contortus eggs and infective larvae. Biomed. Res. Int., 2018: 7375693.

30. Morais-Costa, M., Soares, A.C.M., Bastos, G.A., Nunes, Y.R.F., Geraseev, L.C., Braga, F.C., dos Lima, W.S. and Duarte, E.R. (2015) Plants of the Cerrado naturally selected by grazing sheep may have potential for inhibiting development of Haemonchus contortus larva. Trop. Anim. Health Prod., 47(7): 1321-1328.
31. Molla, S.H. and Bandyopadhyay, P.K. (2016) In vitro and in vivo anthelmintic activity of Murraya koenigii against gastrointestinal nematodes of sheep. J. Parasit. Dis., 40(2): 362-368.

32. Badar, N., Iqbal, Z., Khan, M.N. and Akhtar, M.S. (2011) In vitro and in vivo anthelmintic activity of Acacia nilotica (L.) Willd. Ex delile bark and leaves. Pak. Vet. J., 31(3): 185-191.

33. Kumari, P., Kumar, S., Ramesh, M., Shameena, S., Deo, A.D., Rajendran, K.V. and Raman, R.P. (2019) Antiparasitic effect of aqueous and organic solvent extracts of Azadirachta indica leaf against Argulus japonicus in Carassius auratus. Aquaculture, 511: 634175.

34. Cala, A.C., Ferreira, J.F.S., Chagas, A.C.S., Gonzalez, J.M., Rodrigues, R.A.F., Foglio, M.A., Oliveira, M.C.S., Sousa, I.M.O., Magalhães, P.M. and Junior, W.B. (2014) Anthelmintic activity of Artemisia annua L. extracts in vitro and the effect of an aqueous extract and artemisinin in sheep naturally infected with gastrointestinal nematodes. Parasitol. Res., 113(6): 2345-2353.

35. Tresia, G.E., Evvyernie, D. and Tiuria, R. (2016) Phytochemical screening and in vitro ovicidal, larvacidal, and nematicidal effects of Murraya paniculata (L.) jack extract on gastrointestinal parasites of goats. Med. Peternakan, 39(3): 173-179.

36. Sambodo, P., Prastowo, J., Kurniasih, K. and Indarjulianto, S. (2018) In vitro potential anthelmintic activity of Biophytum petersianum on Haemonchus contortus. Vet. World, 11(1): 1-4.

37. Adamu, M., Mukandiwa, L., Awouafacka, M.D., Ahmeda, A.S., Eloffa, J.N. and Naidoo, V. (2019) Ultrastructure changes induced by the phloroglucinol derivative agrimol $\mathrm{G}$ isolated from Leucosidea sericea in Haemonchus contortus. Exp. Parasitol., 207: 107780.

38. Yoshihara, E., Minho, A.P., Tabacow, V.B.D., Cardim, S.T. and Yamamura, M.H. (2015) Ultrastructural changes in the Haemonchus contortus cuticle exposed to Acacia mearnsii extract. Sem. Ciên. Agrár. Lond., 36(6): 3763-3768.

39. Olivas-Aguirre, F., Wall-Medrano, A., GonzalezAguilar, G., Lopez-Diaz, J.A., Alvarez-Parrilla, E., de la Rosa, A. and Ramos-Jimenez, A. (2015) Taninos hidrozables; bioquimica, aspectos nutricionales y analiticos y efectos en la salud. Nutr. Hosp., 31(1): 55-66. 